\title{
EGOVERNMENT DIGITAL ADOPTION: CAN CHANNEL CHOICE OF INDIVIDUALS BE PREDICTED?
}

\author{
Samantha Papavasiliou and Carmen Reaiche \\ Entrepreneurship, Commercialisation and Innovation Centre, University of Adelaide, \\ Adelaide South Australia
}

\begin{abstract}
The shift of public sector services to digital platforms has had ongoing impacts on individuals interactions with government entities and services. This research explores the effectiveness of encouraging users to adopt an eGovernment channel choice to lodge their annual income tax return in Australia. Through the application of a quasi-randomised control trial, two different user groups were tested in order to compare and contrasts the variable of an early message intervention and the potential impact on the lodgers shift to digital channels (i.e. eGovernment support encouraging historically non-digital lodgers group vs null support). This small study suggests that individuals are encouraged to use digital services when Government provides support, and that they are more likely to displays predictive behaviours of adoption to these digital channels. Furthermore, there are two main characteristics which predict the users choosing to shift (i.e. age and deductive benefits). Through the use of strategically placed encouragement and digital assistance, it makes an individual more likely to shift to digital channels. However, this research demonstrates predictive analytics has a stronger place in the long term adoption of eGovernment services.
\end{abstract}

\section{KEYWORDS}

eGovernment, Digital Adoption, Predictive Analytics

\section{INTRODUCTION}

As the Australian Federal Government mandates the transition within the public sector to digital first service provision, there have been considerable implications to services provided to users in mandatory environments, especially those users who are historically non-digital service users. Service provision in government and the public sector must remain inclusive, and allow for and enable access for users that may prefer or rely on alternative formats. Along with the transition to digital first, the impacts of ongoing technological advances have influenced how governments and public sector organisations are using collected data to provide information and support to 
IADIS International Journal on Computer Science and Information Systems

their citizens. Many of these trends are following the manner in which private sector organisations utilise data, provide services and use predictive analytics. Predictive analytics is the application of several analytical techniques by utilising historical data and behaviours to try and predict the future of behaviours of clients (Nyce 2007; Eckerson 2007). Through the use of predictive analytics different patterns within historical data can be used to identify risks and opportunities for different clients or customers. These patterns are often used to build models to capture the different relationships across factors to identify the set of conditions that could influence future decision making of clients (Coker 2014).

This research tests the potential use of predictive analytics for the provision of advice about some of the key factors potentially influencing users to adopt a specific service and/or channel. Based on the results of a small-scale study to identify the feasibility of the application of predictive analytics (in this case logistic regression) to the public sector. This research was based on the results from a case study on the Australian Taxation Office (ATO), who have been impacted by the creation of the Australian Digital First Policy. The Digital First Policy requires all public sector services to provide digital services as the first point of contact for all organisations (NAA 2015), a policy that was first implemented by the ATO (ATO 2015).

Therefore, this research aims to explore predictive behaviour by addressing the following question:

To what extent an individual's channel choice to digital service use can be predicted? In order to address this question, the testing of the following two propositions were undertaken:

P1: Individuals encouraged to use digital services by Government support, are more likely to change and provide significant factors enabling predictive profile data.

$P 2$ : Characteristics of individuals will predict digital adoption.

The characteristics identified for the purpose of this study are gender, occupation, income, age, tax deduction outcome, and the interaction behaviour with the system.

To appropriately implement predictive analytics, a greater understanding of the users of public sector services (both digital and non-digital channels) is required. This research seeks to explore the potential impacts of providing information about two main channel services: digital to otherwise non digital service users, specifically looking at those requesting paper tax return forms and contacted the ATO within a four week period. In Australia, lodgement of individual income tax returns is mandatory for all individuals and entities who earn or derive income within Australia. Within the literature a gap was identified between what is known about mandatory digital service users, non-users and potential users. As currently research does not focus on the factors which impact adoption or factors that can be used to predict the use of a mandatory digital channel . This research defines mandatory environments as "Public Sector Organisations who must by legislation provide Digital Platforms for their services" (Papavasiliou, Reaiche \& Ricci 2019; Papavasiliou, Reaiche \& Ricci 2019A). While mandatory interactions are defined as "Users who meet certain characteristics and must by legislation interact with the public sector service provider to meet these obligations" (Papavasiliou et al 2019; Papavasiliou et al 2019A). Thus, within mandatory environments individuals must engage with the providers, a process which has evolved since the transition to a digital first channel. Research often does not explore digital adoption or predictive analytics within the mandatory environment; this is where approaches incorporated could aim to be more holistic and inclusive. A holistic and inclusive approach can promote the use of these mandatory digital systems and assist in understanding who of the end users are most likely to change behaviours in choosing and adopting a particular channel. 


\section{LITERATURE}

\section{1 eGovernment}

Increased pressure has been placed on governments with the transition from traditional analogue services channels to electronic or digital services (Yang 2017). Digital societies are comprised of interconnected and multichannel digital services, for governments to successfully perform within these digital societies they must provide high quality and easy to access public sector services (Yang 2017). A key part of this challenge is to meet the service user expectations, while utilising private sector as a benchmark; whereby users expect convenient and diverse communication channels including tailored and proactive information provision (Yang 2017). The societal impacts of the introduction and development of eGovernment services have been considerable. This includes changing the expectations of potential service users including the need for efficient, transparent and effective services as well as utilising all data sources to provide cross channel services. The aim of public sector services is to utilise appropriate channels (including digital) to create more efficient government services, which include providing better and more accessible services and enhancing the quality of life of users (Corydon, Ganesan \& Lundqvist 2016). The digital transformation process is far from simple, however governments who aim to provide services which meet user expectations, empower their users and increase citizen engagement with government, a much more successful long-term approach (Corydon et al 2016).

Technology has enhanced governments businesses and individual opportunities, including how they integrate within the global digital society, and enhance ongoing inclusion (World Economic Forum 2018). In order to become a high functioning digital government, high digital adoption rates are necessary, thus requiring understanding the user's perspective. The key factors impacting eGovernment and digital government services adoption include the level of awareness and level of satisfaction of eGovernment services, factors both linked to intention to use (Yang 2017).

Adoption of eGovernment services is defined as the continuous use of a digital service or innovation (Rogers 1995). To ensure ongoing achievable and sustainable adoption, the digital service needs to be appealing and useful, based on user expectations (Ziemba 2018; Shareef, Dwivedi, Laumer \& Archer 2016). Research has demonstrated that there are several factors that impact a person's willingness to adopt a service, including; human, social and financial capital, level of education and frequency of other digital service use (Hargitti \& Hinnant 2008). A key part of successful and effective eGovernment services are those that are inclusive, which goes beyond access and includes level of digital experience and exposure, digital participation and digital literacy (Hargitti \& Hinnant 2008). Previous literature identified four primary barriers impacting digital access: (1) lack of basic digital experiences due to lack of interest, (2) no computer access, (3) lack of digital skills, and (4) lack of opportunities to use digital services (Van Dijk 1999). Furthermore, additional literature outlines other barriers which impact digital access including lack of access to internet, lack of awareness, language barriers, user friendliness of websites, levels of trust and security fears (Ziemba, Papaj \& Zelazny 2013).

The two primary challenges which impact policy-makers are the allocation of appropriate resources and creating the most effective digital services to support user behaviour (Sawalha, Al-Jamal \& Abu-Shanah 2019). The aim of eGovernment and digital government services is to provide information and public services to citizens in an easy to access manner that encourages 
platform participation (Sawalha, Al-Jamal \& Abu-Shanah 2019). Therefore, it is vital that the service users are understood, to ensure that the potential barriers and factors predicting adoption are known to service designers and policy makers.

\section{2 eGovernment Channel Choice}

There is considerable literature that outlines various factors which influence an individuals' choice to use or adopt a specific service or channel. The majority of research focuses on channel characteristics, situational constraints, personal or demographic factors and task characteristics (Madsen \& Kræmmergaard 2015). Channel characteristics includes elements of the Technology Adoption Model (TAM), including the channels perceived ease of use and perceived usefulness (Pieterson 2010; Barth \& Veit 2011; Mundy, Umer \& Foster 2011; Teerling \& Pieterson 2011). Additional research also discusses levels of interactivity required and the multiple cues in the channels space (Pieterson and van Dijk 2007; Pieterson \& Teerling 2009; Ebbers, Pieterson and Noordman 2008; Pieterson, Teerling and Ebbers 2008; Pang, Mithas \& Lucas 2013; Lee \& Rao 2012). Satisfaction forms a key part of channel choice, this can include the level of satisfaction with a provided channel, this can include the previous encounters with the service and future encounters are often impacted by experiences (Reddick \& Anthopoulos 2014; Reddick \& Turner 2012). Literature also demonstrates the importance of government organisations, illustrating how the various marketing efforts and previous experience with the organisation influence channel choice (Teerling \& Pieterson 2011). This research outlines the importance of more than psychological factors influencing citizens channel choice, especially the role of social processes impacting channel choices.

Additional research discusses the importance of situational constraints impacting channel choice, this includes price, availability and distance to channels (e.g. geographic). Price includes any costs associated with changing to adopt a new channel, this could be travel, purchasing new technology, classes to learn how to use a specific channel and costs associated with time (Verdegem \& Hauttekeete 2008; Reddick 2005). Availability talks about how easy it is to access, where the channel is stored (if it is in person compared to paper or digital), how difficult the process is to obtain access and support to the channel and services (Reddick, Abdelsalam \& Elkadi 2012;). Finally, distance to channel normally includes geographic distance, however distance also includes how far away support services are (Lee \& Rao 2012; Reddick 2005). Channel choices can also be predicted by the characteristics of the tasks involved in the channel or service, this is a complex process. It can include the task at hand and is based on the complexity of the problem and the ambiguity of the information provided to support the undertaking of the task (Barth \& Veit 2011; Vendegem \& Hauttekeete 2008; Reddick 2005; Reddick 2010).

Personal and demographic factors have been used to predict channel choices in individuals in both private and public sector services. There are a variety of socio-demographic factors which have been used to guide the prediction of channel choice, including gender, age, income, occupation code and education levels. In most cases higher levels of income and education were most likely to predict an individual would shift to a digital channel, this is similar for age (where lower age groups were more inclined to shift to digital). (Reddick 2005; Rana, Williams \& Dwivedi 2012). Channel experience is a long-term predictor of channel choice, for example individuals who use digital services from the onset are more inclined to maintain using the channels (Pieterson et al, 2008; Plattfaut, Kohlborn, Hofmann, Beverungen, Niehaves, Rackers 
\& Becker 2013). Previous research also suggests that using paper or non-digital channels, long-term often predict individuals willingness to maintain ongoing use of this channel (Papavasiliou \& Reaiche 2020). In line with the TAM research, levels of trust of public authorities including agencies and service providers, impacts willingness to adopt or choose a specific channel (Reddick 2010; Pang, Mithas and Lucas 2013).

\subsection{Predictive Analytics}

Research suggests that when predictive analytics are appropriately implemented, there are considerable benefits for organisations (Attaran \& Attaran 2019). Research suggests that it is important for organisations to explore the opportunities and challenges of the implementation of predictive analytics into standard organisational applications, by presenting the findings to their leaders, administrators, managers, clients and policymakers (Attaran \& Attaran 2019).

With the rise of big data and its analysis, the use of predictive analytics has become increasingly evident within our everyday lives, from online finances and networked sociality to consumer practices and cultural participation (Barnes \& Wilson 2014). Big data and the application of predictive analytics are a primary component of services including; Google, Netflix, Facebook and Amazon. These services are often used to document everyday activities, classify potential tastes for future options and employ predictive analytics to provide recommendations profiling user's future options (Beer 2013). Predictive analytics has become part of the norm for many organisations, especially in the public sector (Mackenzie 2012). The emergence of big data has had considerable impacts on business, governments, research and society, particularly for analysis' techniques and applications to day-to-day operations (Williamson 2016). Big data is referred to as datasets that contain high volumes of data, which have a comprehensive scope (Kitchin 2014).

Big data and predictive analytics have become a considerable component of government services and citizens' activities, and these have since contributed to digital governance and data driven decision making (Williamson 2014; Lyon 2014). Furthermore, government based big data includes the collection of data that measures, monitoring and governing individuals behaviour (Ruppert 2012). Research by Davies (2012) outlines the emergent style of government whereby ongoing behavioural analysis is undertaken, through advanced analytical techniques to understand, measure and manage the different behaviours of individuals and groups. Furthermore, Bowker (2005) states that this type of governmental analysis and organisation, is one that is more engaging, is closely tied with the world and citizens and represents the real world more closely. In the predictive analytics space there is considerable research exploring its application in different domains, based on different factors and in different countries, these are outlined in Table 1. This literature highlights the variability in the application of predictive analytics in both private and public sectors. 
IADIS International Journal on Computer Science and Information Systems

Table 1. Literature on Predictive Analytics

\begin{tabular}{|c|c|}
\hline Research & References \\
\hline $\begin{array}{l}\text { Researched whether they could predict a customer's intention to } \\
\text { switch a mobile service provider, they found that if the barrier to } \\
\text { switching is high they will not. }\end{array}$ & Shin \& Kim 2008 \\
\hline $\begin{array}{l}\text { Explored the role of big data and predictive analysis on increasing } \\
\text { cybersecurity, this research was based on understanding the role } \\
\text { of behavioural analytics. }\end{array}$ & $\begin{array}{l}\text { Eastman, Versace \& Webber } \\
2015\end{array}$ \\
\hline $\begin{array}{l}\text { Conducted research applies learning analytics to track and predict } \\
\text { student performance, with results helping to inform educational } \\
\text { policy. }\end{array}$ & Williamson 2015 \\
\hline $\begin{array}{l}\text { Explored the willingness of individuals to utilise mobile } \\
\text { government applications, using UTAUT for predicting acceptance } \\
\text { criteria (strongest being performance expectancy and trust). }\end{array}$ & $\begin{array}{l}\text { Sharma, Al-Badi, Rana \& Azizi } \\
2018\end{array}$ \\
\hline $\begin{array}{l}\text { Explored the factors that can assist in the predictive of } \\
\text { adolescence remission of internet addiction, finding several } \\
\text { factors including low interpersonal sensitivity and hostility } \\
\text { predicted remission. }\end{array}$ & Ko, Yen, Yen, Lin \& Yang 2007 \\
\hline $\begin{array}{l}\text { Found seven factors that predict adoption of assistive technology } \\
\text { in people with dementia. }\end{array}$ & $\begin{array}{l}\text { Zhang, McClean, Nugent, } \\
\text { Donnelly, Galway, Scotney \& } \\
\text { Cleland } 2014\end{array}$ \\
\hline $\begin{array}{l}\text { Predicting policing was used in Kent County Police, which found } \\
\text { that past conditions and adoption strategies play a crucial role in } \\
\text { the acceptance of new and innovative work practices that utilise } \\
\text { ICT. }\end{array}$ & Asquer 2015 \\
\hline $\begin{array}{l}\text { Predicted the adoption of IT in SMEs based on a model utilising } \\
\text { social, economic, psychological and environmental variables. }\end{array}$ & $\begin{array}{l}\text { Ukoha, Awa, Nwuche \& Asiegbu } \\
2011\end{array}$ \\
\hline $\begin{array}{l}\text { Found that the telemedicine Service acceptance model predicts } \\
\text { the factors for the acceptance of telemedicine services in } \\
\text { physicians. }\end{array}$ & Rho, Choi \& Lee 2014 \\
\hline $\begin{array}{l}\text { Found that cognitive and affective gratification-seeking factors } \\
\text { were strong predictors and adopter attributes were moderate } \\
\text { predictors of online service adoption as a result of advertisements. }\end{array}$ & Lin 2001 \\
\hline $\begin{array}{l}\text { Found that three separate IS models all provide different } \\
\text { explanatory variables for the adoption of eBusiness services } \\
\text { (these included; the technology-organization-environment model, } \\
\text { the task-technology-fit model, and the unified theory of } \\
\text { acceptance and use of technology). }\end{array}$ & Trang, Zander \& Kolbe 2014 \\
\hline $\begin{array}{l}\text { Found that one trust related construct (perceived credibility) and } \\
\text { two resource related constructs (self-efficacy and perceived } \\
\text { financial resources) predict consumers' intention to use mobile } \\
\text { services. }\end{array}$ & Wang, Lin \& Luarn 2006 \\
\hline $\begin{array}{l}\text { Utilising Technology Acceptance Model found that by adding } \\
\text { three factors: experience, trust and time, they could predict the } \\
\text { acceptance of M-government services. }\end{array}$ & $\begin{array}{l}\text { Airowili, Alotaibi \& Alharbi } \\
2015\end{array}$ \\
\hline $\begin{array}{l}\text { Found that perceived usefulness was the strongest predictor of } \\
\text { intention to use information systems in the Indonesian } \\
\text { Government Agency. }\end{array}$ & $\begin{array}{l}\text { Mardiana, Tjakraatmadja \& } \\
\text { Aprianingish } 2015\end{array}$ \\
\hline
\end{tabular}




\section{METHOD}

This study utilised a Quasi Randomised-Control Trial (QRCT) and case study on the ATO to understand the impact of encouraging the use of digital services to otherwise non-digital service users. A section of the results of this data collection were also outlined within Papavasiliou, Reaiche \& Ricci (2019A), however additional analysis was conducted to determine if the behaviours could be predicted and if so what individuals (based on specific characteristics) were more likely to change or maintain a behaviour. A QRCT differs from the standard RCT, as there is no set sample size and the allocation to treatment and control group is random (Gribbons \& Herman 1997).

The QRCT was conducted in July 2018 (over a four week period). To conduct this study, 11 call centre operatives in the ATO were provided a script to use as a 'treatment'. The number of participants (calls) were random, to be selected for treatment the participant needed to call the ATO and request a non-digital lodgement option for their 2018 tax return. If the participant was put through to one of the treatment call centre operatives, they would be informed of the digital service offer, the benefits and be aided to complete their lodgement. Whereas if they were not put through to one of the treatment operatives they were provided no information about digital services and sent out the paper lodgement forms.

To ensure the validity of the treatment and control group, the basic participant demographics were compared to one and other to ensure similarities between the groups (e.g. age, gender, occupation and income). After the four week period the treatment group was comprised of $\mathrm{N}=254$ and the control group was comprised of $\mathrm{N}=2534$ participants. Therefore, this QRCT was testing whether through an encouragement (i.e. eGoverment support) an individual who previously lodged via non-digital means (with no previous history of lodging through digital channels) would shift to a digital lodgement channel. In comparison to not making a change in the channel chosen for lodgement of tax return or obtaining support and lodging through a tax intermediary or agent. Therefore, addressing the research question highlighted above.

\subsection{Logistic Regression}

Through the application of a binomial logistic regression, the analysis was able to explore who was more likely to shift to digital services after obtaining the treatment. A logistic regression was utilised to describe the data and explain the relationship between one dependant variable (binary variable) and an independent variable (either ordinal, interval or nominal) (Menard 2002). The purpose of applying a logistic regression is to measure the unique impacts of each independent variable on the dependent variable. Through the use of a binomial two dimensional logistic regression means that the dependent variable is binary, meaning that the variable only has two possible values (Harrell 2015). The interpretation of the binary logistic regression is to predict which of the two groups the binary dependent variable individuals sit within (Harrell 2015). The logistic regression was conducted in R statistical software, utilising the glm function for binomial logistic regression. To create the model, the dataset was split into a training and test group (75\% training and $25 \%$ testing). A number of different independent variables were tested to determine the most useful variables for predicting the outcome. 


\section{RESULTS}

The first part of the analysis was to determine if the encouragement to use Digital Lodgement had been effective. While also assessing whether the shift from previous lodgement channel to tax agent lodgement was effective and consistent. Table 2 shows the count of the individuals who used each method of lodgement for both the treatment and control groups. It appears that the treatment group (those encouraged to use the digital service) contains more individuals who lodged digitally than the control group. This is also similar to the change in behaviour from paper lodgement to tax agent lodgement.

To formally test this, a Chi-squared $\left(\chi^{2}\right)$ test was applied to these data resulting in a p-value of 0 . For the individuals within the treatment group, those who lodged their return using either a Tax Agent or Digital Lodgement was far higher than otherwise expected, and the number who completed the Paper Lodgement was far lower than otherwise expected. The control group had the inverse effect. This strongly suggests that the intervention of encouraging individuals to use the digital service was effective. However, an unintentional consequence to the ambiguity in the messaging provided to clients was the large shift from paper to tax agent lodgement.

Table 2. Digital and non-digital lodgement by treatment and control group

\begin{tabular}{|l|l|l|l|}
\hline & $\begin{array}{l}\text { Paper } \\
\text { lodgement }\end{array}$ & $\begin{array}{l}\text { Tax Agent } \\
\text { Lodgement }\end{array}$ & $\begin{array}{l}\text { Digital } \\
\text { Lodgement }\end{array}$ \\
\hline Treatment & 149 & 61 & 44 \\
\hline Control & 229 & 14 & 10 \\
\hline
\end{tabular}

The next analysis was to break down the demographics of each group to investigate whether these could be used to understand which individuals were likely to respond to the treatment. Table 3 outlines the demographic information that was collected for each individual and indicates whether or not is was used in the logistic regression. This information also highlights the characteristics evaluated that could be significant in predicting digital adoption.

Table 3. Demographic variables tested in the logistic regression

\begin{tabular}{|l|l|l|l|}
\hline Independent Variable & Definition Included/Excluded & $\begin{array}{l}\text { Why } \\
\text { Excluded/Included }\end{array}$ \\
\hline Gender & $\begin{array}{l}\text { Three categories: } \\
\text { Male, Female and Not } \\
\text { Stated }\end{array}$ & Excluded & $\begin{array}{l}\text { Not enough variability in } \\
\text { the distribution }\end{array}$ \\
\hline Dependent indicator & $\begin{array}{l}\text { Y or N field that } \\
\text { indicates if the } \\
\text { individual has } \\
\text { dependents (e.g. } \\
\text { children) }\end{array}$ & Excluded & All individuals had N \\
\hline $\begin{array}{l}\text { Supplementary } \\
\text { Income Indicator }\end{array}$ & $\begin{array}{l}\text { indicates whether an } \\
\text { individual that } \\
\text { supplementary has } \\
\text { income (e.g. rental, } \\
\text { dividends or shares). }\end{array}$ & Included & $\begin{array}{l}\text { Only a small number of } \\
\text { individuals had Y Y } \\
\text { relevant for the use of tax } \\
\text { agents }\end{array}$ \\
\hline
\end{tabular}




\begin{tabular}{|c|c|c|c|}
\hline $\begin{array}{l}\text { Occupation Code } \\
\text { Group }\end{array}$ & $\begin{array}{l}10 \text { categories }(1-10) \\
\text { that outlines which } \\
\text { occupation the } \\
\text { individual is within }\end{array}$ & Excluded & $\begin{array}{l}\text { Too much variability and } \\
\text { grouping together } \\
\text { decreases the amount of } \\
\text { available information }\end{array}$ \\
\hline $\begin{array}{l}\text { Government Income } \\
\text { Indicator }\end{array}$ & $\begin{array}{l}\text { Y or } \mathrm{N} \text { field that } \\
\text { indicates if the } \\
\text { individual received } \\
\text { government income or } \\
\text { pension }\end{array}$ & Included & $\begin{array}{ll}\text { Predominately } & \text { Y } \\
\text { indicators which were } \\
\text { useful for tax agent } \\
\text { channel }\end{array}$ \\
\hline Spouse Indicator & $\begin{array}{l}\text { Y or N field that } \\
\text { indicates if the } \\
\begin{array}{l}\text { individual had a } \\
\text { spouse }\end{array}\end{array}$ & Included & $\begin{array}{l}\text { Were useful in the choice } \\
\text { to use tax agents }\end{array}$ \\
\hline Age Range & $\begin{array}{l}3 \text { categories: } \\
<45,45-64 \text { and } 65+ \\
\text { Grouped in this way } \\
\text { due to the small } \\
\text { sample size }\end{array}$ & Included & \\
\hline Deductions Indicator & $\begin{array}{l}\text { Y or } \mathrm{N} \text { field that } \\
\text { indicates if the } \\
\text { individual had } \\
\text { claimed deductions on } \\
\text { the tax lodgement }\end{array}$ & Included & \\
\hline
\end{tabular}

A binomial logistic regression model was used to investigate which characteristics were significant in switching away from Paper Lodgement. The type of lodgement in 2018 ( 1 for Digital lodgement, and 0 for Paper lodgement) was predicted by Gender, Age Range, Supplementary Income Indicator, and Deduction Indicator.

As outlined in Table 3 a number of variables were found to be insignificant in this analysis. Table 4 shows the final results of the model for digital channel use and the coefficients of the characteristics which were found to be significant.

Table 4. Results of the binomial logistic regression for Digital Channel use

\begin{tabular}{|l|l|l|l|}
\hline Category & Option & Coefficient & P-value \\
\hline Age Range (Years) & $45-64$ & -1.1157 & 0.005 \\
& $65+$ & -1.9484 & $6.64 \times 10^{-6}$ \\
\hline Deduction Indicator & Y & 2.5629 & $4.36 \times 10^{-10}$ \\
\hline
\end{tabular}

The Age range coefficients were found to be significant for predicting the switch to the Digital Lodgement. As the model uses a logit link, the coefficients are exponentiated to get a measure of the change involved. Thus, individuals younger than 45 years were 3 times more likely to switch to Digital Lodgement than individuals aged 45-65 years. Individuals younger than 45 were 7 times more likely to switch to Digital Lodgement than individuals aged 65 years and over. The Deduction Indicator was also found to be significant. Individuals who claimed deductions were almost 13 times more likely to switch to Digital Lodgement than those individuals who did not claim deductions.

A binomial logistic regression model was used to investigate which characteristics were significant in switching away from Paper Lodgement to using a tax agent or intermediary. The type of lodgement in 2018 ( 1 Tax Agent lodgement, and 0 for Paper lodgement) was predicted 
IADIS International Journal on Computer Science and Information Systems

by Gender, Age Range, Supplementary Income Indicator, Government Income Indicator and Deduction Indicator.

As outlined in Table 3 a number of variables were found to be insignificant in this analysis. Table 4 shows the final results of the model for tax agent channel use and the coefficients of the characteristics which were found to be significant.

Table 5. Results of the binomial logistic regression for Tax Agent/ Intermediary Channel use

\begin{tabular}{|l|l|l|l|}
\hline Category & Option & Coefficient & P-value \\
\hline Age Range (Years) & $18-45$ & -1.1257 & 0.005 \\
& $65+$ & -1.9477 & $6.34 \times 10^{-6}$ \\
\hline Deduction Indicator & $\mathrm{Y}$ & 2.3541 & $4.34 \times 10^{-10}$ \\
\hline $\begin{array}{l}\text { Government Income } \\
\text { Indicator }\end{array}$ & $\mathrm{N}$ & 2.2251 & $4.21 \times 10^{-10}$ \\
\hline $\begin{array}{l}\text { Supplementary } \\
\text { Indicator }\end{array}$ & $\mathrm{Y}$ & 2.5639 & $4.37 \times 10^{-10}$ \\
\hline
\end{tabular}

The Age range coefficients were found to be significant for predicting the switch to the Tax Agent Lodgement channel. As the model uses a logit link, the coefficients are exponentiated to get a measure of the change involved. Thus, individuals between than 45 and 64 years were 3 times more likely to switch to a tax agent Lodgement than individuals aged 18 to 45 years. Individuals aged between 45 and 64 were 7 times more likely to switch to Digital Lodgement than individuals aged 65 years and over. The Deduction Indicator was also found to be significant. Individuals who claimed deductions were almost 13 times more likely to switch to Digital Lodgement than those individuals who did not claim deductions. Similarly, those individuals who claimed supplementary income was also found to be significant, they were almost 13 times more likely to switch to Tax Agent Lodgement than those individuals who did not claim deductions. While individuals who do not claim government income was significant, it was 12 times more likely to switch to a tax agent than those who did claim one.

The results of this study demonstrate that the intervention works well and could be extended to additional populations. Interestingly, the results of the regression shows that the intervention is working better for some individuals in comparison to other, namely young people and people who claim deductions within their tax lodgement. The results also demonstrate that there is no significant difference between the change to digital service behaviours of males or females. There was also no difference between people with supplementary income and those who don't have supplementary income in whether they changed their lodgement practice

The results of this study demonstrate a correlation between a number of factors making an individual more likely to change from non-digital to digital services with encouragement. However, the research question remains unanswered and the hypothesis is neither disproven nor proven in this instance, as the predictive power of data is not robust.

In sum, and adopting an interpretative approach of the results presented above, this study indicates that the early intervention and support had a positive impact on the choice of channel, which appears to have been significantly increased by the age group representative of the younger cluster. Simultaneously, the same intervention has negatively affected the choice of digital channels and has been perceived to altered the choice of channels to the ones representative of tax agents. The choice for tax agents have had no significant influence to the choice of channel from the young age cluster. As final predictive factors with significant influence on digital channel adoption, the analytics shows 'age' and 'deduction' to be predominant (see figure 1). 


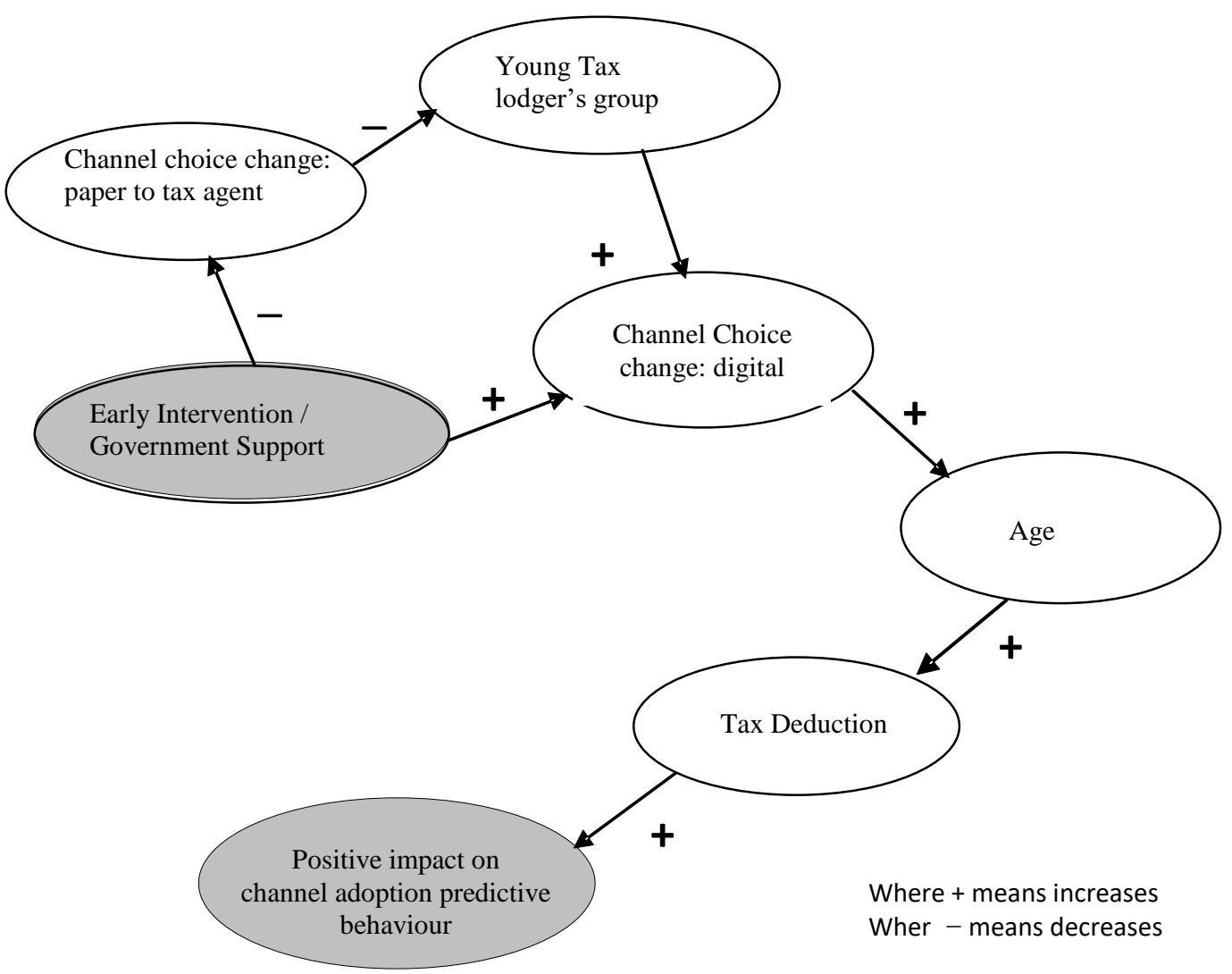

Figure 1. An Interpretative approach to key results

\section{IMPLICATIONS AND FUTURE RESEARCH}

The findings of this study demonstrate proposition 1 is supported, that is the effectiveness of encouraging historically non digital service users to transition to digital services for the lodgement of their annual tax returns in Australia. The results demonstrate a number of factors which make an individual more likely to change their behaviour with encouragement. The research suggests that more encouragement could be provided to individuals aged between 45 and 64 years old to explain the benefits of utilising digital services and even extending to provide greater assistance. The intervention would require alterations to be more tailored to the individuals aged 65 onwards. 
IADIS International Journal on Computer Science and Information Systems

Preposition 2 was partially supported, as it was found that Age and Deduction indicator were two main characteristics enabling a digital predictive behaviour. However, further research is required to predict the correlation of these two main characteristics and the significance of eGoverment support / encouragement. In particular, future research is proposed to address who out of the encouragement trial group would be most effective in adopting digital services and who in long term sustains a digital behaviour across various digital services.

The predictive analytic literature has emphasised the fact that e-government users will benefit from the services as a regular channel of accessing and interacting with digital information. Empirically, this research has shown that if e-government expands their support and informative sessions, users will adopt the digital channel as they can see the convenience access to their tax information and in turn a prompt response to tax deductions. The conclusions that have emerged from the analysis presented in this study can be summarised as follow:

- Although predictive analytics already exists within the ATO and other eGoverment services that explores user's digital adoption, there still opportunities to expand on the standardisation of psychological behaviours to an in-depth exploration of social practices. An integration of these analytics can potentially strengthen predictive behaviours, which can shape future digital systems designs across sectors.

- As per table 4 described earlier, a couple of factors (such as age and deduction indicator) were identified and therefore considered important for understanding users' decisions for adopting digital channels.

- The full potential of eGovernment services, particularly in mandatory environments, are unlikely to be realised without a high rate adoption from users across all age groups. Efforts from e-government training and support within one of the major predictive factors (i.e. tax deductions) can potentially be use as driver to promote digital adoption. The benefits can be equally perceived at all age groups.

Understanding users' predictive behavioural intention to choose a channel and intention to recommend of e-participation platforms is critical for eGoverment services that aim to implement the use of those technologies as mandatory systems. Future research can focus on extending this study to other eGovernment services, and draw comparative analysis of predictive factors in adoption as well as exploring correlation of these factors to users' satisfaction.

\section{REFERENCES}

Australian Taxation Office (ATO)., 2015. Reinventing the ATO Blueprint, Available from: [Online] https://www.ato.gov.au/uploadedFiles/Content/.../programblueprint-march-2015.pdf. Retrieved: 12 November 2018.

National Archives of Australia (NAA)., 2015. Digital Continuity2020. Available from: [Online] www.naa.gov.au/Information.management/Digital.Continuity.2020. Retrieved: 12 November 2018.

Alrowili, T.F., Alotaibi, M.B., \& Alharbi., M.S., 2015. Predicting Citizens' Acceptance of M-Government Services in Saudi Arabia an Empirical Investigation. Proceedings of the Annual IEEE Systems Conference, Vancouver, Canada, pp. 627-633. 
Asquer., A., 2015. Big Data and Innovation in the Delivery of Public Services: The Case of Predictive Policing, in Handbook of Research on Democratic Strategies and Citizen-Centred eGovernment Services. Dolicanin C, Kajan E, Randjelovic D and Stojanovic B (eds). IGI Global, USA.

Attaran, M., \& Attaran, S., (2019). Opportunities and Challenges of Implementing Predictive Analytics for Competitive Advantage. In Applying Business Intelligence Initiatives in Healthcare and Organizational Settings. Miah, S.J., and Yeoh, W. (eds). IGI Global, USA, pp. 35-84.

Barnes, T.J., \& Wilson, M.W., 2014. Big Data, Social Physics, and Spatial Analysis: The Early Years. Big Data \& Society, vol.1, No.1, pp. 1-14.

Barth, M., \& Veit, D., 2011. Electronic Service Delivery in the Public Sector: Understanding the Variance of Citizens' Resistance. Proceedings of 44th Hawaii International Conference in System Sciences, Hawaii, USA, pp. 1-11.

Beer., D., 2013. Popular Culture and New Media: The Politics of Circulation. Palgrave Macmillan, London.

Bowker, G.C., 2005. Memory Practices in the Sciences. MIT Press, London.

Corydon, B., Ganesan., V. \& Lundqvist, M., 2016. Digital by Default: A Guide to Transforming Government [Online]. Available from: https://www.mckinsey.com/ /media/mckinsey/industries/public\%20sector/our\%20insights/transform ing\%20government\%2 0through\%20digitization/digital-by-default-a-guide-to- transforminggovernment.ashx 2016. Retrieved: 10 November 2018.

Davies., W., 2012. The Emerging Neocommunitarianism. The Political Quarterly, vol. 83, No. 4, pp. 767-776.

Eastman, R., Versace. M., \& Webber, A., 2015. 'Big Data and Predictive Analytics: On the Cybersecurity in the Front Line', [Online]. Available from: http://northshorechoral.com/millerjw/dom/gsb622online/week5/GSB\%20622\%20MIS\%20IDC\%20 \%20Big\%20Data\%20and\%20Predictive\%20Analytics\%20\%200n\%20the\%20Cybersecurity\%20Fro nt\%20Line.pdf, Retrieved: 10 November 2018.

Ebbers, W., Pieterson, W., \& Noordman, H., 2008. Electronic Government: Rethinking Channel Management Strategies. Government Informatics Quarterly, vol.25, No. 2, pp.181-201.

Edwards, P.N., Jackson, S.J., Chalmers, M.K., Bowker, G.C., Borgaman, C.L., Ribes, D., Burton, M., \& Calvert, S., 2013. Knowledge Infrastructures: Intellectual Frameworks and Research Challenges. Ann Arbor, Deep Blue.

Gribbons, B., \& Herman, J., 1997. True and Quasi-Experimental Designs' Practical Assessment. Research \& Evaluation. Vol. 5, No. 14.

Hargitti E and Hinnant A., 2008. Digital Inequality: Differences in Young Adults' Use of the Internet. Communication Research, vol.35, No. 5, pp.602-621.

Harrell, F.E., 2015. Regression Modeling Strategies. Springer Series in Statistics (2nd ed.). Springer, New York.

Kitchin, R., 2014. Big Data, New Epistemologies and Paradigm Shifts. Big Data \& Society, vol. 1, No. 1, pp. 1-12.

Ko, C.H., Yen, J.Y., Yen, C.F., Lin, H.C., \& Yang, M.J., 2007. Factors Predictive for Incidence and Remission of Internet Addiction in Adolescents: A Prospective Study. Cyber Psychology and Behaviour, vol. 10, No. 4, pp. 545-551.

Lee, J., \& Rao, H.R., 2012. Service Source and Channel Choice in G2C Service Environments: A Model Comparison in the Anti/Counter-Terrorism Domain. Information Systems Journal, vol.22, No. 4, pp. 313-341.

Lin, C.A., 2001. Audience Attributes, Media Supplementation, and Likely Online Service Adoption. Mass Communication and Society, vol. 4, No. 1, pp. 19-38.

Lyon, D., 2014. Surveillance, Snowden and Big Data: Capacities, Consequences, Critique. Big Data \& Society, pp. 1-13. 
IADIS International Journal on Computer Science and Information Systems

Mackenzie, A., 2012. More Parts than Elements: How Databases Multiply. Environment and Planning D: Society and Space, vol. 30, pp. 335-350.

Menard, S.W., 2002. Applied Logistic Regression (2nd ed.). SAGE, New York.

Mundy, D., Umer, Q., \& Foster, A., 2011. Examining the Potential for Channel Shift in the UK Through Multiple Lenses. Electronic Journal of eGovernment, vol. 9, No. 2, pp.203-213.

Papavasiliou S., \& Reaiche, C., 2020. eGovernment Digital Adoption: Can the Adoptive Behaviour of Individuals be Predicted, In Proceedings of the $18^{\text {th }}$ International Conference e-Society, Sofia, Bulgaria, pp. 11-18.

Papavasiliou, S., Reaiche, C., \& Ricci, P., 2019. Digital Adoption: The Need for Truly Inclusive e-Government Services. In the Proceeding of the 2019 International Conference on E-Learning, E-Business, Enterprise Information Systems \& E-Government, Las Vegas, USA, pp. 43-49.

Papavasiliou, S., Reaiche, C., \& Ricci, P., 2019A. Digital Interactions Strategy: A Public Sector Case. In the Proceedings of the Thirteenth International Conference on Digital Society and eGovernments. Athens, Greece, pp. 19-23.

Pang, M., Mithas, S., \& Lucas, H., 2013. How Channel Choice and Service Failure Influence Customer Satisfaction: The Case of Public Services. In the Proceedings of the Thirty Fourth International Conference on Information Systems, Milan, Italy, pp. 1-20.

Pieterson, W., 2010. Citizens and Service Channels: Channel Choice and Channel Management Implications. International Journal of Electronic Government Research, vol. 6, No. 2, pp. 37-53.

Pieterson, W., \& Teerling, M., 2009. Channel Integration in Governmental Service Delivery: The Effects on Citizen Behavior and Perceptions. In EGOV LNCS. Wimmer, M.A., Scholl, H.J., Janssen, M., and Traunmüller, R. (eds.), vol. 5693, pp. 222-233. Springer, Heidelberg

Pieterson, W., Teerling, M., \& Ebbers, W., 2008. Channel Perceptions and Usage: Beyond Media Richness Factors. In EGOV LNCS. Wimmer, M.A., Scholl, H.J., and Ferro, E. (eds.), vol. 5184, pp. 219-230. Springer, Heidelberg.

Pieterson, W., \& van Dijk, J., 2007. Channel Choice Determinants; An Exploration of the Factors that Determine the Choice of a Service Channel in Citizen Initiated Contacts. In the Proceedings of the 8th Annual International Conference on Digital Government Research, Pennsylvania, USA, vol. 228, pp.173-182.

Plattfaut, R., Kohlborn, T., Hofmann, S., Beverungen, D., Niehaves, B., Rackers, M., \& Becker, J., 2013. Unravelling eGovernment Channel Selection: A Quantitative Analysis of Individual Customer Preferences in Germany and Australia. 46th Hawaii International Conference on System Science, Hawaii, USA, pp.1983-1991.

Reddick, C., 2005. Citizen-Initiated Contacts with Government: Comparing Phones and Websites. Journal of eGovernment, vol. 2, No. 1, pp. 27-53.

Reddick, C. (2010). "Comparing Citizens' Use of eGovernment to Alternative Service Channels". International Journal of Electronic Government Research, vol. 6, pp.54-67.

Reddick, C., Abdelsalam, H.M.E., \& Elkadi, H.A., 2012. Channel Choice and The Digital Divide in eGovernment: The Case of Egypt. Information Technology Development, Vol. 18, No. 3, pp.226-246.

Reddick, C., \& Anthopoulos, L., 2014. Interactions with eGovernment, New Digital Media and Traditional Channel Choices: Citizen-Initiated Factors. Transform. Gov. People, Process Policy, vol. 8, No.3, pp.398-419.

Reddick, C., \& Turner, M., 2012. Channel Choice and Public Service Delivery in Canada: Comparing eGovernment to Traditional Service Delivery. Government Informatics Quarterly, Vol. 29, No. 1, pp. 1-11.

Rogers, E.M., 1995. Diffusion of Innovation, New York, Free Press.

Rho, M.J., Choi, I.Y., \& Lee, J., 2014. Predictive Factors of Telemedicine Service Acceptance and Behavioural Intention of Physicians. International Journal of Medical Informatics, Vol. 83, No. 8, pp. 559-571. 
Ruppert, E. 2012. The Governmental Topologies of Database Devices. Theory, Culture \& Society, Vol. 29, No.4-5, pp. 116-136.

Sawalha, S., Al-Jamal, M., \& Abu-Shanab, E., 2019. The Influence of Utilising Facebook on e-government Adoption. Electronic Government, vol.15, No.1, pp.1-20.

Shareef, M.A., Dwivedi, Y.K., Laumer, S., \& Archer, N., 2016. Citizens' Adoption Behaviour of Mobile Government (mGov): A Cross-Cultural Study. Information Systems Management, vol.33, No.3, pp.268-283.

Sharma, S.K., Al-Badi, A., Rana, N., \& Al-Azizi, L., 2018. Mobile Applications in Government Services (mG-App) from User's Perspectives: A Predictive Modelling Approach. Government Information Quarterly, vol. 35, No. 4, pp. 557-568.

Shin, D.H., \& Ko, W.Y., 2008. Forecasting Customer Switching Intention in Mobile Service: An Exploratory Study of Predictive Factors in Mobile Portability. Technological Forecasting and Social Change, vol. 75, No. 6, pp. 854-874.

Teerling, M., \& Pieterson, W., 2011. How to Improve eGovernment Use: An Empirical Examination of Multichannel Marketing Instruments, Information Polity, vol.16, No. 2, pp.171-187.

Trang, S., Zander, S., \& Kolbe, L., 2014. eBusinesss Adoption at the Firm Level: Comparing the Predictive Power of Competing IS Adoption Models. ICIS 2014 Proceedings, Auckland, New Zealand.

Ukoha, O., Awa, H.O., Nwuche., A, \& Asiegbu, I., 2011. Analysis of Explanatory and Predictive Architectures and the Relevance in Explaining the Adoption of IT in SME's. Interdisciplinary Journal of Information, Knowledge and Management, vol. 6, pp. 217-229.

Van Dijk, J., 1999. The Network Society; Social Aspects of New Media, Sage, Thousand Oaks.

Verdegem, P., \& Hauttekeete, L., 2008. The User at the Centre of the Development of One-Stop Government. International Journal of Electronic Government, vol. 1, No. 3, pp. 258-274.

Williamson, B., 2014. Knowing Public Services: Cross-sector Intermediaries and Algorithmic Governance in Public Sector Reform. Public Policy and Administration, vol. 29, No. 4, pp. 292-312.

Williamson, B., 2016. Digital Education Governance: Data Visualisation, Predictive Analytics and 'Real-Time' Policy Instruments, Journal of Education Policy, vol. 31, No. 2, pp. 123-141.

World Economic Forum., 2018. Our Shared Digital Future; Building an Inclusive, Trustworthy and Sustainable Digital Society [Online]. Available from: http://www3.weforum.org/docs/WEF_Our_Shared_Digital_F uture_Report_2018.pdf. Retrieved: 10 July 2019.

Yang, Y., 2017. Towards a New Digital Era: Observing E- Government Services Adoption in a Chinese Municipality. Future Internet, Vol. 9, No. 53, pp. 21-17.

Zhang, S., McClean, S.I., Nugent, C.D., Donnelly, M.P., Galway, L., Scotney, B.W., \& Cleland, I., 2014. A Predictive Model for Assistive Technology Adoption in People with Dementia. Journal of Biomedical and Health Informatics, vol. 8, No.1, pp. 325-383.

Wang, Y.S., Lin, H.H., \& Luarn, P., 2006. Predicting Consumer Intention to Use Mobile Service. Information Systems Journal, vol. 16, No. 2, pp. 157-179.

Ziemba, E., 2018. The Contribution of ICT Adoption to Sustainability: Households' Perspective. Information Technology and People, Vol. 32, No.3, pp.731-753.

Ziemba, E., Papaj, T., \& Zelazny, R., 2013. A Model of Success Factors for E-Government Adoption The Case of Poland. Issues in Information Systems, Vol.14, No. 2, pp.87-100. 